\title{
CELL CYCLE ARREST ACTIVITY OF LITSEA CUBEBA LOUR: HEARTWOOD AND FRUIT EXTRACTS AGAINST T47D BREAST CANCER CELLS
}

\author{
AMINAH DALIMUNTHE ${ }^{1 *}$, POPPY ANJELISA Z HASIBUAN ${ }^{1}$, DENNY SATRIA ${ }^{2}$ \\ ${ }^{1}$ Department of Pharmacology, Faculty of Pharmacy, University of Sumatera Utara, Medan, Indonesia. ${ }^{2}$ Department of Pharmaceutical \\ Biology, Faculty of Pharmacy, University of Sumatera Utara, Medan, Indonesia. Email: aminahdalimunthe@usu.ac.id
}

Received: 25 May 2017, Revised and Accepted: 11 July 2017

\section{ABSTRACT}

Objective: This study was carried out to investigate cell cycle arrest activity toward T47D cells of Litsea cubeba heartwoods and fruits extract.

Methods: Dry extracts were prepared from dry-grounded heartwoods and fruits by cold maceration using n-hexane, ethylacetate, and ethanol solvent. Cytotoxic activity were measured by [3-(4,5-dimethylthiazole-2-yl)-2,5-diphenyl tetrazolium bromide] methods and interpreted with inhibitory concentration $50 \%\left(\mathrm{IC}_{50}\right)$ value. Cell cycle arrest was investigated by flowcytometry method.

Results: $\mathrm{IC}_{50}$ values for each n-hexane, ethylacetate, and ethanol of $L$. cubeba heartwoods and fruits were $76.34 \pm 2.61 ; 67.52 \pm 2.45 ; 71.23 \pm 2.37$; $75.59 \pm 3.24 ; 162.58 \pm 15.08 ; 63.70 \pm 2.67 \mu \mathrm{g} / \mathrm{mL}$, respectively. Cell cycle arrest for ethylacetate extract of heartwoods and fruits were accumulated in $\mathrm{G}_{0} / \mathrm{G}_{1}$ phase $(56.70 \%$ and $65.56 \%)$.

Conclusion: These results suggest that L. cubeba heartwoods and fruits has cell cycle arrest activity.

Keywords: Cell cycle arrest, Litsea cubeba, Heartwood, Fruit, Extract.

(c) 2017 The Authors. Published by Innovare Academic Sciences Pvt Ltd. This is an open access article under the CC BY license (http://creativecommons. org/licenses/by/4. 0/) DOI: http://dx.doi.org/10.22159/ajpcr.2017.v10i11.20204

\section{INTRODUCTION}

The World Health Organization reported that breast cancer is one of the leading cause of death and the most common cancer type among women worldwide in 2012 [1]. Moreover, breast cancer ranks as the $5^{\text {th }}$ cause of death from cancer overall $(522,000$ deaths $)$ is the most frequent cause of cancer death in women in less developed countries (324,000 deaths, $14.3 \%$ of total), and the $2^{\text {nd }}$ cause of cancer death in developed countries $(198,000$ deaths, $15.4 \%)$ after lung cancer. A previous study reported that breast cancer is predicted to be a leading new cancer cases and the $2^{\text {nd }}$ most common death cause of women suffering from cancer in the US [2]. Therefore, research and development in cancer detection and treatment is importantly required to solve those problems.

Attarasa (Litsea cubeba Lour.) is a plant from Lauraceae family which contains much essential oils which used as antideppresant, antiinflammation, antioxidant, pesticide, antimicrobial, anticancer, and neuropharmacology [3]. Methanol extract from attarasa fruits showed to be activeoncervics cancer (HeLa cell lines) which cause apoptosis through activation of caspase 3/7 [3,4]. There are more than forty isoquinolin alkaloids that contained in Litsea genus which are active as antibacterial agents against Staphylococcus aureus [5]. The heartwoods of L. cubeba contained high level of phenolic and flavonoid and found to be active as antioxidant [6]. The aim of this study was to determine cytotoxic activity and cell cycle arrest of $L$. cubeba Lour. heartwoods and fruits on T47D cells.

\section{METHODS}

Plant and chemicals material

Fresh barks and fruits of L. cubeba (Lour.) was collected from Balige subdistrict, Sumatera Utara province. L. cubeba (Lour.) was identified in Research Center for Biology, Indonesian Institute of Science, Bogor, and the voucher specimen was deposited in herbarium. Chemicals used were distilled water, dimethyl sulfoxide (Sigma), ethanol (Merck), ethylacetate (Merck), [3-(4,5-dimethylthiazole-2-yl)-2,5-diphenyl tetrazolium bromide] (MTT) (Sigma), propium iodide (BioLegend), and n-hexane (Merck).

Preparation of $\mathbf{n}$-hexane, ethylacetate, and ethanol extract The air-dried and powdered heartwods and fruits of L. cubeba (Lour.) $(1 \mathrm{~kg})$ were repeatedly extracted by cold maceration with $\mathrm{n}$-hexane $(3 \times 3 \mathrm{~d}, 7.5 \mathrm{~L})$. The powder which has been extracted with $\mathrm{n}$-hexane was dried in the air and extracted with ethylacetate $(3 \times 3 \mathrm{~d}, 7.5 \mathrm{~L})$ and continued with ethanol $(3 \times 3 \mathrm{~d}, 7.5 \mathrm{~L})$ at room temperature with occasional stirring. The filtrate was collected, and then, evaporated under reduced pressure to give a viscous extract and then freeze dried to dry [6-9].

\section{Cytotoxicity assay}

The cells were treated with n-hexane, ethylacetate, and ethanol extract. In this test, T47D cell line was grown in RPMI 1640 medium, medium containing $10 \%$ fetal bovine serum (Gibco), $1 \%$ penicillin-streptomycin (Gibco), and Fungizone $0.5 \%$ (Gibco) in a flask in $5 \% \mathrm{CO}_{2}$ at $37^{\circ} \mathrm{C}$ conditions. The inoculums seeded at $1 \times 10^{4}$ cells $/ \mathrm{mL}$ at an optimal volume of $100 \mu \mathrm{L}$ per well. After $24 \mathrm{hrs}$ incubation, the medium was discharged and treated with extracts and doxorubicin. After incubation $24 \mathrm{hrs}$, the T47D cells were incubated with $0.5 \mathrm{mg} / \mathrm{mL}$ MTT for 4-6 hrs in $37^{\circ} \mathrm{C}$. Viable cells were reacted with MTT to produce purple formazan crystals. After $4 \mathrm{hrs}$, sodium dodecyl sulfate $10 \%$ as stopper (Sigma) in $0.01 \mathrm{~N} \mathrm{HCl}$ (Merck) was added to dissolve the formazan crystals. The cells were incubated for overnight in room temperature and protected from light. After incubation, the cells were shaken, and absorbance was measured using microplate reader at $\lambda 595 \mathrm{~nm}$. The data which were absorbed from each well were converted to percentage of viable cells $[8,10-14]$.

Cell cycle analysis

T47D cells $\left(5 \times 10^{5}\right.$ cells/well) were seeded into 6-well plate and incubated for $24 \mathrm{hrs}$. After that, the cells were treated with extract and 
then incubated for $24 \mathrm{hrs}$. Cells were collected in conical tube using tripsin $0.025 \%$. The cells were washed 3 times with cold phosphatebuffered saline (PBS) and centrifuged at $2500 \mathrm{rpm}$ for 5 minutes. The supernatant was separated, while the sediment was collected $[7,15]$. Cells were fixed in $70 \%$ cold ethanol in PBS at $-20^{\circ} \mathrm{C}$ for $2 \mathrm{hr}$. The cells were washed 3 times with cold PBS and resuspended then centrifuged at $3000 \mathrm{rpm}$ for 3 minutes and PI kit (containing PI $40 \mu \mathrm{g} / \mathrm{mL}$ and RNAse $100 \mu \mathrm{g} / \mathrm{mL}$ ) added to sediment and resuspended and incubated at $37^{\circ} \mathrm{C}$ for 30 minutes. The samples were analyzed using FACScan flow cytometer. Based on DNA content, percentage of cells in each of stage in cell cycle (G1, S, and G2/M) were calculated using ModFit Lt. 3.0.s $[12,13,16]$.

\section{Statistical analysis}

Data were expressed as mean \pm SD. All statistics were analyzed using the SPSS 20 software.

\section{RESULTS AND DISCUSSION}

\section{Plant authentication}

Plant authentication was identified in Research Center for Biology, Indonesian Institute of Science, Bogor, and the voucher specimen was deposited in herbarium with number 1859/IPH.1.01/If.07/IX/2015 and was showed species of L. cubeba (Lour.)

Inhibitory concentration $50 \%\left(\right.$ IC $\left._{50}\right)$

MTT method was used to determine cell viability after incubation for 24 hrs. Cytotoxic activity of n-hexane, ethylacetate, and ethanol extract of heartwoods and fruits of L. cubeba was showed in Table 1 .

In every treatment, n-hexane, ethylacetate, ethanol, and doxorubicin were shown to inhibit cells growth. The highest $\mathrm{IC}_{50}$ value was obtained from ethanol extract of $L$. cubeba fruits of $63.70 \pm 2.67 \mu \mathrm{g} / \mathrm{mL}$ and $\mathrm{IC}_{50}$ of doxorubicin as positive control was $0.20 \pm 0.18 \mu \mathrm{g} / \mathrm{mL}$. The estimated cytotoxicity of natural product is related to content of active compound in these plants including L. cubeba. Flavonoids, triterpenoids/steroids, volatile oils, and alkaloids estimated as active compounds [17]. Doxorubicin is one of chemotherapeutic agent for breast cancer patient therapy. T47D cells line underwent resistant to doxorubicin due to p53 mutation $[18,19]$.

\section{Cell cycle arrest activity}

To investigate the activity of ethylacetate extract of heartwoods (EAEH) and fruits (EAEF) is by measuring the cell death by modulating cell cycle, we focused on it on further studies using flow cytometry method. The activity of EAEH and EAEF are presented in Fig. 1 and Table 2. Whereas treatment of EAEH and EAEF with $10 \mu \mathrm{g} / \mathrm{mL}$ caused cell accumulation at $\mathrm{G}_{0} / \mathrm{G}_{1}$ phase were $56.70 \%$ and $65.56 \%$ and for control cell was $45.37 \%$. At $\mathrm{S}$ phase, the accumulation after EAEH and EAEF treatment were $19.81 \%$ and $15.19 \%$ and for control cell was $18.57 \%$. This fact indicated that EAEH and EAEF can inhibit cell grow that $\mathrm{G}_{0} / \mathrm{G}_{1}$ phase but EAEH inhibit in $S$ phase as well. In the cell cycle analysis, EAEH and EAEF exhibited higher $G_{0} G_{1}$ and $S$ phase accumulation compared to control cells. This analysis also showed that cells underwent apoptosis, indicated by the occurence of apoptosis during inhibition of cell cycle on $G_{0}-G_{1}$ phase $[7,16]$.

From cell cycle analysis (Table 2) was shown that EAEH and EAEF significantly induced cell cycle arrest on T47D breast cancer cells at $\mathrm{G}_{0}-\mathrm{G}_{1}$ phase. EAEH and EAEF contain various secondary metabolites such as alkaloids, flavonoids, saponins, and tannins which affected cell cycle arrest. A number of anticancer agents derived from plants are also reported to inhibit cancer cell growth by blocking cell cycle progression such as quercetine (a polyphenol) arrested breast cancer cells at $\mathrm{G}_{1}$ or $\mathrm{G}_{2} / \mathrm{M}$ phase [20], curcumin (derived from turmeric of Curcuma genus) caused $\mathrm{G}_{2} / \mathrm{M}$ arrest in bladder cancer cells [21], and gambogic acid (isolated from gamboge resin of Garcinia hanburryi) inhibited the growth of gastric carcinoma cells by inducing $\mathrm{G}_{2} / \mathrm{M}$ arrest [22]. Lycorine is one of alkaloids which inhibits cell cycle progression and induces cell cycle arrest in the G0/G1 phase in K562 cells [23].

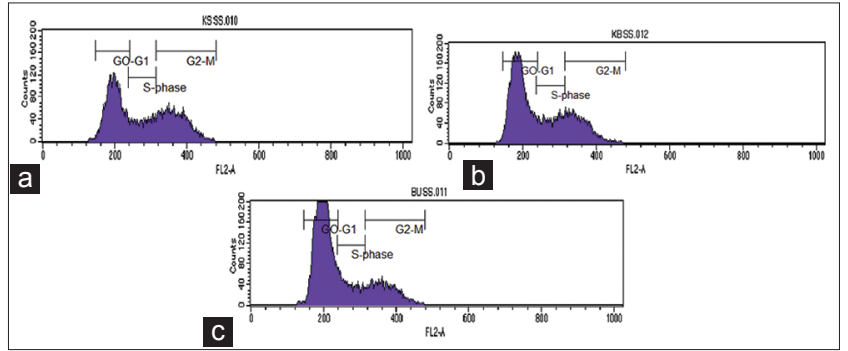

Fig. 1: Cell cycle analysis using flow cytometry. T47D cells were treated by ethylacetate extract of heartwoods (EAEH) and fruits (EAEF) for $24 \mathrm{hrs}$ and stained using propidium iodide. (a) Control cells, (b) EAEH $10 \mu \mathrm{g} / \mathrm{mL}$, and (c) EAEF $10 \mu \mathrm{g} / \mathrm{mL}$. EAEH and EAEF exhibited G0/G1 phase and decreased T47D cell population

Table 1: $\mathrm{IC}_{50}$ value of $\mathrm{n}$-hexane, ethylacetate, and ethanol extract of $L$. cubeba heartwoods and fruit toward T47D cells

\begin{tabular}{lll}
\hline Treatment with extract & $\mathbf{I C}_{\mathbf{5 0}}(\boldsymbol{\mu g} / \mathbf{m L})$ & \\
\cline { 2 - 3 } & Heartwood & Fruit \\
\hline n-hexane & $76.34 \pm 2.61$ & $67.52 \pm 2.45$ \\
Ethylacetate & $71.23 \pm 2.37$ & $75.59 \pm 3.24$ \\
Ethanol & $162.58 \pm 15.08$ & $63.70 \pm 2.67$ \\
Doxorubicin & $0.20 \pm 0.18$ & \\
\hline
\end{tabular}

$\mathrm{IC}_{50}$ : Inhibitory concentration 50\%, L. cubeba: Litsea cubeba

Table 2: Cell cycle arrest percentage after treatment with EAEH and EAEF

\begin{tabular}{lllll}
\hline \multirow{2}{*}{ Treatment } & Concentration $(\boldsymbol{\mu g} / \mathbf{m L})$ & \multicolumn{4}{l}{ Phase $(\%)$} \\
\cline { 3 - 5 } & & $\mathbf{G}_{\mathbf{0}}-\mathbf{G}_{\mathbf{1}}$ & $\mathbf{S}$ & $\mathbf{G}_{\mathbf{2}}$-M \\
\hline Control & - & 45.37 & 18.57 & 36.06 \\
EAEH & 10 & 56.70 & 19.81 & 24.05 \\
EAEF & 10 & 65.56 & 15.19 & 20.08 \\
\hline
\end{tabular}

EAEH: Ethylacetate extract of heartwoods, EAEF: Ethylacetate extract of fruits

\section{ACKNOWLEDGMENTS}

We gratefully thank to Rector University of Sumatera Utara, Indonesia through "TALENTA" Research Grant 2016 for financial support in the study. The authors thank to Prof. Dr. Jansen Silalahi, M.App. Sc., Apt. and Mr. Harald Braun for assistance with the English.

\section{REFERENCES}

1. WHO. World Cancer Report 2014. Geneva: WHO; 2015.

2. Siegel RL, Miller KD, Jemal A. Cancer statistics, 2015. CA Cancer J Clin 2015;65(1):5-29.

3. Trisonthi P, Sato A, Nishiwaki H, Tamura H. A new diterpene from Litsea cubeba fruits: Structure elucidation and capability to induce apoptosis in HeLa cells. Molecules 2014;19(9):6838-50.

4. Piyapat T, Kana M, Hirotoshi T. Induction of apoptosis in hela cells by methanolic extract of Litsea cubeba fruit residue from essential oil extraction. J Life Sci 2013; 7:928-34.

5. Feng T, Zhang RT, Tan QG, Zhang XY, Liu YP, Cai XH, et al. Two new isoquinoline alkaloids from Litsea cubeba. z. Naturforsch 2009;64:871-4.

6. Dalimunthe A, Achmad S, Satria D. Phenolic, flavonoid content and antioxidant activities of ethylacetate extract of Litsea cubeba (lour.) pers. barks. Der Pharm Chem 2016;8:466-8.

7. Satria D, Furqan M, Hadisahputra S, Rosidah. Combinational effects of ethylacetate extract of picria fel-terrae lour and doxorubicin on $477 \mathrm{~d}$ breast cancer cells. Int J Pharm Pharm Sci 2015;7:73-6.

8. Hasibuan PA, Jessy C, Satria D. Combination effect of ethylacetate extracts of Plectranthus ambonicius (lour.) spreng. with doxorubicin againts t47d breast cancer cells. Int J Pharm Pharm Sci 2015;7:155-9.

9. Sihotang YM, Silalahi J, Hadisahputra S, Hasibuan PA, Satria D. 
Cardioprotective effect of ethylacetate extract of poguntano (Picria felterrae lour.) against doxorubicin-induced cardiotoxicity in rats. Int $\mathrm{J}$ Pharm Clin Res 2016;8:466-70.

10. Meiyanto E, Hermawan A, Junedi S, Fitriasari A, Susidarti RA. Nobilatin increased cytotoxic activity of doxorubicin on mcf-7 cells but not on t47d cells. Int J Phytomed 2011;3:129-37.

11. Nugroho AE, Ikawati M, Hermawan A, Putri DD, Meiyanto E. Cytotoxic effect of ethanolic extract fractions of Indonesia plant Ficus septica Burm. F. on human breast cancer $\mathrm{t} 47 \mathrm{~d}$ cell lines. Int J Phytomed 2011;3:216-26.

12. Nurrochmad A, Lukitaningsih E, Meiyanto E. Anti cancer activity of rodent tuber (Thyphonium flagelliforme (lodd.) blume on human breast cancer t47d cells. Int J Phytomed 2011;3:138-46.

13. Nugroho AE, Hermawan A, Putri DD, Novika A, Meiyanto E, Kawaichi M. Combinational effects of hexane insoluble fraction of Ficus septica Burm. F. and doxorubicin chemotherapy on T47D breast cancer cells. Asian Pac J Trop Biomed 2013;3(4):297-302.

14. Satria D, Nasution NP, Ilyas S. Cytotoxcicity effect of sea horse (Hippocampus trimaculatus leach.) extract and fractions on mcf-7 cell line. Int J Pharm Technol Res 2014;6:212.

15. Anggraini R, Hadisahputra S, Silalahi J. Combinational effects of ethylacetate extract of Zanthoxylum acanthopodium Dc. with doxorubicin on $\mathrm{t} 47 \mathrm{~d}$ breast cancer cells. Int $\mathrm{J}$ Pharm Technol Res 2014;6(7):2032-5

16. Satria D, Silalahi J, Haro G, Ilyas S, Hsb PA. Antioxidant and antiproliferative activities of an ethylacetate fraction of picria fel-terrae lour. Herbs Asian Pac J Cancer Prev 2017;18(2):399-403.

17. Yadav VR, Sahdeo P, Bokyung S, Ramaswamy K, Bharat BA. Targetting inflammatory pathways by triterpenoids for prevention and treatment of cancer. Toxins 2012;2:2428-66.

18. Di Leo A, Tanner M, Desmedt C, Paesmans M, Cardoso F, Durbecq V, et al. p-53 gene mutations as a predictive marker in a population of advanced breast cancer patients randomly treated with doxorubicin or docetaxel in the context of a phase III clinical trial. Ann Oncol 2007;18(6):997-1003

19. Vayssade M, Haddada H, Faridoni-Laurens L, Tourpin S, Valent A, Bénard $\mathrm{J}$, et al. P73 functionally replaces p53 in adriamycin-treated, p53-deficient breast cancer cells. Int J Cancer 2005;116(6):860-9.

20. Choi HJ, Lim DY, Park JH. Induction of $\mathrm{g} 1$ and $\mathrm{g} 2 / \mathrm{m}$ cell cycle arrests by the dietary compound 3,3'-diindolylmethane in ht-29 human colon cancer cells. BMC Gastroenterol 2009;9:39.

21. Park WH. Anti-apoptotic effect of caspase inhibitors on $\mathrm{H} 2 \mathrm{O} 2$-treated HeLa cells through early suppression of its oxidative stress. Oncol Rep 2014;31(5):2413-21.

22. Yu Jh, Liu CY, Zheng GB, Zhang LY, Yan MH, Zhang WY, et al. Pseudolaric acid B induced cell cycle arrest, autophagy and senescence in murine fibrosarcoma 1929 cell. Int J Med Sci 2013;10(6):707-18.

23. Li L, Da HJ, Mao Y, Wang SL, Xiao XJ. Lycorine induces cell-cycle arrest in the G0/G1 phase in K562 cells via HDAC inhibition. Cancer Cell Int 2012;12:2-6 